\title{
Tissue Destruction in Bullous Pemphigoid Can Be Complement Independent and May Be Mitigated by $\mathrm{C} 5 \mathrm{aR} 2$
}

\begin{abstract}
Christian M. Karsten ${ }^{1 \dagger}$, Tina Beckmann ${ }^{2 \dagger}$, Maike M. Holtsche ${ }^{3}$, Jenny Tillmann ${ }^{1}$, Sabrina Tofern², Franziska S. Schulze ${ }^{2}$, Eva Nina Heppe ${ }^{2}$, Ralf J. Ludwig'2, Detlef Zillikens ${ }^{3}$, Inke R. König ${ }^{4}$, Jörg Köhl1,5 and Enno Schmidt ${ }^{2,3 *}$
\end{abstract}

\begin{abstract}
Institute of Systemic Inflammation, University of Lübeck, Lübeck, Germany, ${ }^{2}$ Lübeck Institute of Experimental Dermatology (LIED), University of Lübeck, Lübeck, Germany, ${ }^{3}$ Department of Dermatology, University of Lübeck, Lübeck, Germany, ${ }^{4}$ Institute of Medical Biometry and Statistics, University of Lübeck, Lübeck, Germany, ${ }^{5}$ Division of Immunobiology, Cincinnati Children's Hospital and College of Medicine, University of Cincinnati, Cincinnati, $\mathrm{OH}$, United States
\end{abstract}

\section{OPEN ACCESS}

Edited by:

Massimo Gadina,

National Institute of Arthritis and Musculoskeletal and Skin Diseases,

United States

Reviewed by:

Takashi Hashimoto,

Osaka City University Graduate School of Medicine, Japan

Gang Wang,

Fourth Military Medical

University, China

*Correspondence:

Enno Schmidt

enno.schmidt@uksh.de

tThese authors have contributed equally to this work.

Specialty section: This article was submitted to Inflammation,

a section of the journal

Frontiers in Immunology

Received: 16 January 2018 Accepted: 23 February 2018

Published: 15 March 2018

Citation:

Karsten CM, Beckmann T, Holtsche MM, Tillmann J, Tofern S, Schulze FS, Heppe EN, Ludwig RJ,

Zillikens $D$, König IR, Köhl J and Schmidt E (2018) Tissue Destruction

in Bullous Pemphigoid Can Be

Complement Independent and May Be Mitigated by C5aR2.

Front. Immunol. 9:488. doi: 10.3389/fimmu.2018.00488
Bullous pemphigoid (BP), the most frequent autoimmune bullous disorder, is a paradigmatic autoantibody-mediated disease associated with autoantibodies against BP180 (type XVII collagen, Col17). Several animal models have been developed that reflect important clinical and immunological features of human BP. Complement activation has been described as a prerequisite for blister formation, however, the recent finding that skin lesions can be induced by anti-Col17 $\mathrm{F}\left(\mathrm{ab}{ }^{\prime}\right)_{2}$ fragments indicates complement-independent mechanisms to contribute to blister formation in BP. Here, $\mathrm{C5}^{-/-}$mice injected with anti-Col17 lgG showed a reduction of skin lesions by about $50 \%$ associated with significantly less skin-infiltrating neutrophils compared to wild-type mice. Reduction of skin lesions and neutrophil infiltration was seen independently of the employed antiCol17 IgG dose. Further, C5ar1-/- mice were protected from disease development, whereas the extent of skin lesions was increased in C5ar2 ${ }^{-/-}$animals. Pharmacological inhibition of C5a receptor 1 (C5aR1) by PMX53 led to reduced disease activity when applied in a prophylactic setting. In contrast, PMX-53 treatment had no effect when first skin lesions had already developed. While C5aR1 was critically involved in neutrophil migration in vitro, its role for Col17-anti-Col17 lgG immune complex-mediated release of reactive oxygen species from neutrophils was less pronounced. Our data demonstrate that complement-dependent and -independent mechanisms coexist in anti-Col17-autoantibody-mediated tissue destruction. C5aR1 and C5aR2 seem to play opposing roles in this process with C5aR1 exerting its primary effect in recruiting inflammatory cells to the skin during the early phase of the disease. Further studies are required to fully understand the role of C5aR2 in autoantibody-mediated skin inflammation.

\section{Keywords: autoantibody, dermal-epidermal junction, BP180, type XVII collagen, skin, treatment}

\section{INTRODUCTION}

Type XVII collagen (Col17), also termed BP180, is a component of the dermal-epidermal junction (DEJ) and target antigen in various subepidermal blistering autoimmune disorders, the most frequent being bullous pemphigoid (BP) (1-4). The majority of BP sera reacts with epitopes clustered within the 16th non-collagenous (NC16A) domain of Col17 (5). Due to the relatively low homology between human NC16A and the corresponding murine NC15A domain, direct evidence for the 
functional relevance of antihuman (h)Col17 was only successful after Nishie et al. had expressed $h C O L 17$ in mice $(6,7)$. Before, the passive transfer of rabbit antibodies generated against murine and hamster Col17 in neonatal animals had resulted in a subepidermal blistering phenotype mimicking important immunopathological signs of human $\mathrm{BP}(8,9)$.

The neonatal mouse model based on the passive transfer of rabbit antimurine collagen type XVII (anti-mCol17) IgG has vigorously been explored by the group of Liu and Diaz that highlighted the pathogenic importance of, e.g., complement activation, inflammatory cells such as neutrophils, mast cells, and macrophages, and the release of proteolytic enzymes at the DEJ in this model [(8), reviewed in Ref. (10)]. Of note, complement activation appeared to be pivotal in this model as shown by several lines of evidence: $C 5$ - and $C 4$-deficient $\left(^{-/-}\right)$mice were completely protected against the pathogenic effect of anti-mColli IgG, and pharmacological inhibition of $\mathrm{C} 1 \mathrm{q}$ as well as complement depletion by cobra venom prevented skin lesions in the neonatal mouse model of BP $(11,12)$. Furthermore, in this model, factor $\mathrm{B}(\mathrm{CFB})^{-/-}$mice developed delayed and less intense blistering and the $\mathrm{C} 5 \mathrm{a}$ receptor $1(\mathrm{C} 5 \mathrm{aR} 1)$ on mast cells was shown to be critical for the formation of skin lesions $(12,13)$. In addition, mutated non-C1q-binding anti-hCol17 IgG1 was not capable to induce BP lesions in neonatal COL17-humanized mice (14). More recently, however, in neonatal mice, the injection of $\mathrm{F}\left(\mathrm{ab}^{\prime}\right)_{2}$ fragments of BP patients' IgG and rabbit anti-hCOL17 IgG resulted in skin fragility questioning the impact of complement activation for lesion formation in BP (15).

To further clarify the role of complement activation in the pathogenesis of BP and to explore the potential therapeutic use of complement inhibitors that are increasingly being developed (16), we made use of a recently established passive transfer model of BP in adult mice (17). In this model, the injection of rabbit IgG generated against the murine homolog (amino acids 497-573) of the immunodominant human NC16A domain of BP180 in adult $\mathrm{C} 57 \mathrm{BL} / 6$ or Balb/c mice on days $2,4,6,8$, and 10 triggered an inflammatory reaction that mimicked major characteristics of the human disease including (i) complement-fixing IgG along the DEJ, (ii) spontaneous erythema and erosions arising from day 4, (iii) subepidermal blisters by histopathology, and (iv) lesional infiltration of neutrophils and eosinophils. Furthermore, skin lesions develop over some days and thus, this model is suitable to study anti-inflammatory mediators in a quasitherapeutic setting, i.e., in mice with already established skin lesions (17).

Here, the extent of BP skin lesions was markedly reduced in $C 5^{-1-}$ mice as compared to wild-type mice and pathogenicity was mediated by $\mathrm{C} 5 \mathrm{aR} 1$, while $\mathrm{C} 5 \mathrm{aR} 2$ was protective. Pharmacological inhibition of $\mathrm{C} 5 \mathrm{aR} 1$ as well as in vitro analyses indicated that complement activation may exert its major pathophysiological impact in the early phase of the disease through the regulation of neutrophil accumulation in the skin.

\section{MATERIALS AND METHODS}

\section{Mice}

C57BL/6J, Balb/c, Fcer ${ }^{-1-}$ mice (B6;129P2-Fcertm1Rav $\left./ J\right), C 5 a r 1^{-/-}$ (on C57BL/6 background), and ${\mathrm{C} 5 \mathrm{ar} 2^{-/-}}$mice (for in vivo experiments on Balb/c background, for in vitro experiments on C57BL/6 background) were bred and housed at $12 \mathrm{~h}$ light-dark cycle at the experimental animal facility in the University of Lübeck. $\mathrm{C}^{-1-}$ mice (B10.D2-Hc $\mathrm{H}^{0} 2^{d} \mathrm{H} 2-\mathrm{T} 18^{c} / \mathrm{oSnJ}$ ) and the corresponding wild-type controls (B10.D2- $H c^{1} H 2^{d} H 2-T 18^{c} /$ $\mathrm{nSnJ}$ ) were obtained from Jackson Laboratories (Bar Harbor, ME, USA). All injections and bleedings were performed on eight to twelve-week old mice narcotized by intraperitoneal (i.p.) injection of a mixture of ketamine $(100 \mu \mathrm{g} / \mathrm{g})$ and xylazine $(15 \mu \mathrm{g} / \mathrm{g})$.

Animal experiments were approved by the Animal Care and Use Committee of Schleswig-Holstein (Kiel, Germany; 21-2/11, 40-3/15) and performed by certified personnel.

\section{Generation and Characterization of Rabbit Antibodies to mCol17}

The extracellular portion of the 15th non-collagenous domain (NC15A) of mCol17 covering the stretch directly adjacent to the transmembrane domain (amino acids 497-573) was expressed as glutathione- $S$-transferase (GST) fusion protein and purified by affinity chromatography as previously described (18). Pathogenic anti-mCol17 IgG was generated in New Zealand white rabbits as reported $(17,19)$. Normal rabbit serum was obtained from CCPro (Oberdorla, Germany).

\section{EndoS Preparation and IgG Hydrolysis In Vitro}

Pretreatment of rabbit IgG was performed as previously described $(20,21)$. One milligram of rabbit anti-mCOL17 IgG was incubated with $5 \mu \mathrm{g}$ recombinant GST-EndoS in PBS for $16 \mathrm{~h}$ at $37^{\circ} \mathrm{C}$ followed by affinity removal of GST-EndoS by serial passages over Glutathione-Sepharose 4B columns (GE Healthcare, Uppsala, Sweden). IgG hydrolysis was verified by SDS-PAGE and lectin blot analyses as previously described (21).

\section{Passive Transfer Mouse Model}

Affinity-purified rabbit anti-mCol17 IgG and normal rabbit IgG, respectively, was injected subcutaneously into the neck of mice every second day over a period of 12 days at individual doses of 7.5 or $10 \mathrm{mg} / \mathrm{ml} \mathrm{IgG} \mathrm{unless} \mathrm{stated} \mathrm{otherwise.} \mathrm{At} \mathrm{the} \mathrm{time} \mathrm{of}$ IgG injections, mice were weighed and examined for their general condition and evidence of cutaneous lesions (i.e., erythema, blisters, erosions, and crusts). Cutaneous lesions were scored as involvement of the skin surface as previously described $(17,22)$. At day 12, all mice were sacrificed, blood was taken, and both lesional and perilesional biopsies were taken for histopathological analysis (stored in 4\% buffered formalin) and direct IFM (stored at $-80^{\circ} \mathrm{C}$ ), respectively. C5a receptor antagonist PMX53 was provided by Dr. Trent Woodruff (University of Queensland, Brisbane, Australia). $20 \mu \mathrm{g}$ of PMX53 per mouse were daily injected i.p. from days 0 to 11 and from days 4 to 11 , respectively.

\section{Immunofluorescence Microscopy and Histopathology}

Tissue-bound autoantibodies and complement deposits were detected by direct IF microscopy of frozen sections using FITC-conjugated rabbit antimouse IgG (1:100; Dako, Hamburg, 
Germany), FITC-conjugated murine antimouse C3 (1:50; Cappel, MP Biomedicals, Solon, OH, USA), and murine antimouse C5 antibody (1:100; Cell Sciences, Canton, MA, USA) detected by FITC-labeled rabbit antimouse IgG (1:100; Dako). Staining was evaluated using a Keyence BZ-9000 microscope (Keyence, NeuIsenburg, Germany) and quantified using ImageJ (http://rsbweb. nih.gov/ij/) software. Formalin-fixed skin samples were processed into paraffin blocks. Four micrometer sections were stained with hematoxylin and eosin according to standard protocols.

\section{Neutrophil-Specific Myeloperoxidase (MPO) Activity}

Myeloperoxidase activity, corresponding to the total granulocyte infiltration, was assessed in homogenized ear-specimens as described in previous protocols (23). MPO content was expressed as units of MPO activity per milligram of protein. Protein concentrations were determined by a dye binding assay (Thermo Scientific, Rockford, IL, USA) using bovine serum albumin as a standard.

\section{Neutrophil Preparation}

Mouse neutrophils were purified as previously described (24). Briefly, bone marrow cells from femurs and tibiae were flushed, red blood cells lysed with hypotonic $\mathrm{NaCl}$ and cells were separated by $62.5 \%$ Percoll $^{\circledR}$ (GE Healthcare, Uppsala, Sweden) gradient. For higher purity of neutrophils, T- and B-cells were depleted by MACS separation with anti-CD3 $\varepsilon$ and anti-CD19 antibodies (Miltenyi Biotech, Bergisch Gladbach, Germany). Purity of neutrophils was consistently $>90 \%$ as determined by FACS analysis.

\section{Reactive Oxygen Species (ROS) Release Assay}

In this assay, intra- and extracellular ROS of neutrophils was measured using luminol-amplified chemiluminescence after incubation with immune complexes and various controls, respectively, as described previously $(25,26)$. In brief, 96-well plates were coated with $20 \mathrm{mg} / \mathrm{ml}$ of mCol17 NC15A overnight. After blocking with PBS containing 1\% BSA and 0.05\% Tween20 (PBS-T), $1 \mathrm{mg} / \mathrm{ml}$ rabbit anti-mColl7 IgG was incubated for $1 \mathrm{~h}$ at $37^{\circ} \mathrm{C}$. After washing with PBS-T untreated or heatinactivated $\left(30 \mathrm{~min}, 56^{\circ} \mathrm{C}\right)$ mouse serum or recombinant $\mathrm{C} 5 \mathrm{a}$ (R\&D Systems Inc., Minneapolis, MN, USA) diluted in $100 \mu \mathrm{l}$ of chemiluminescence medium were added to the immune complexes. $100 \mu \mathrm{l}$ of cell suspension $\left(2 \times 10^{6} / \mathrm{ml}\right)$ containing $60 \mu \mathrm{g} / \mathrm{ml}$ of luminol (5-amino-2,3-dihydro-1,4-phthalazindione; Sigma Aldrich, Hamburg, Germany) was given to each well and generation of ROS was determined in a microplate luminometer (Wallac 1420 VICTOR TM, Perkin Elmer, Waltham, MA, USA). Chemiluminescence data were expressed as relative light units. Data are derived from at least two independent experiments performed in quadruplicates.

\section{Migration Assay}

Chemotaxis of bone-marrow-derived cells was performed as described previously (27). Briefly, bone-marrow neutrophils were collected as described above and then resuspended in chemotaxis medium (HBSS containing 2\% BSA) at a density of $5 \times 10^{6}$ cells $/ \mathrm{ml}$. As a chemoattractant, we used C5a $(12.5 \mathrm{nM}$; Hycult, Uden, Netherlands), which was diluted in chemotaxis medium. The chemoattractant was placed in the bottom wells of a modified Boyden chamber (Neuro Probe, Gaithersburg, MD, USA) and overlaid with a $3 \mu \mathrm{m}$ polycarbonate membrane. Then, $50 \mu \mathrm{l}$ of the cell suspension were placed in the top wells of the assembled Boyden chamber and incubated at $37^{\circ} \mathrm{C}$ in $5 \% \mathrm{CO}_{2}$ for $30 \mathrm{~min}$. Subsequently, the membranes were removed and the cells on the bottom of the membrane stained with Diff-Quick (Merck, Darmstadt, Germany). The numbers of migrated cells for each well were counted in five different high-power fields and the number of cells per $\mathrm{mm}^{2}$ was calculated by computerassisted light microscopy. Results are expressed as the mean value of triplicate samples of at least two independent set of experiments.

\section{Statistical Analysis}

Sigma plot 11.0 (Systat Software Inc., Chicago, IL, USA) and $\mathrm{R}$ version 3.4.0 (April 21, 2017) (http://www.r-project. $\mathrm{org} /$ ) were used to perform statistical analyses. $p$-Values were determined by Mann-Whitney $U$-tests for comparisons between two independent groups, Kruskal-Wallis tests for comparisons between more than two independent groups, nd non-parametric analyses of variance for comparisons including different time points. For the latter, we employed the $\mathrm{R}$ package nparLD (28).

\section{RESULTS}

\section{Complement Deposition at the DEJ Does Not Correlate with Disease Activity in Experimental BP}

Adult mice lacking the activating $\gamma$-chain of the $F c$ receptor $\left(\right.$ Fcer $\left.^{-1-} ; n=5\right)$, the FcyRIV $\left(F c g r 4^{--}, n=5\right)$, and the FcyRIIB $\left(\right.$ Fcgr $\left.^{-/-}, n=5\right)$, respectively, as well as wild-type C57BL/6J animals $(n=5)$ were injected with rabbit anti-Col17 IgG and EndoS-treated Col17-specific IgG $(n=5)$, respectively. EndoS, an endoglycosidase that specifically hydrolyzes the N-linked glycan on IgG heavy chains $(20,29)$, reduces the binding to activating $F_{c} \gamma R$, and increases the binding to the inhibiting FcyRIIB $(20,29)$. Disease activity was greatly reduced in $\mathrm{Fcer}^{-1-}$ and $\mathrm{Fcgr4}^{-1-}$ mice as well as in mice injected with EndoS-pretreated anti-Col17 IgG, whereas Fcgr2 ${ }^{-1-}$ mice showed significantly more skin lesions compared to wild-type animals as shown previously (17). MPO activity determined in extracts of an entire ear reflected disease activity and was significantly higher in Fcgr $2^{-/-}$mice $(p<0.001)$ and significantly lower in Fcgr4 $4^{-1-}$ mice $(p<0.01)$ compared to wild-type animals (Figure 1). Of note, the intensity of bound anti-C3 and anti-C5 IgG at the DEJ as detected by direct IF microscopy of perilesional skin biopsies taken at day 12 was not different compared to wild-type animals $\left(\right.$ Fcer $^{-1-}, p=0.69, p=0.22 ;$ Fcgr $^{-1-}, p=0.73, p=0.56 ;$ Fcgr $^{-l-}$, $p=0.90, p=0.63$; EndoS-pretreated IgG, $p=0.92, p=0.26$; Figure 1). 


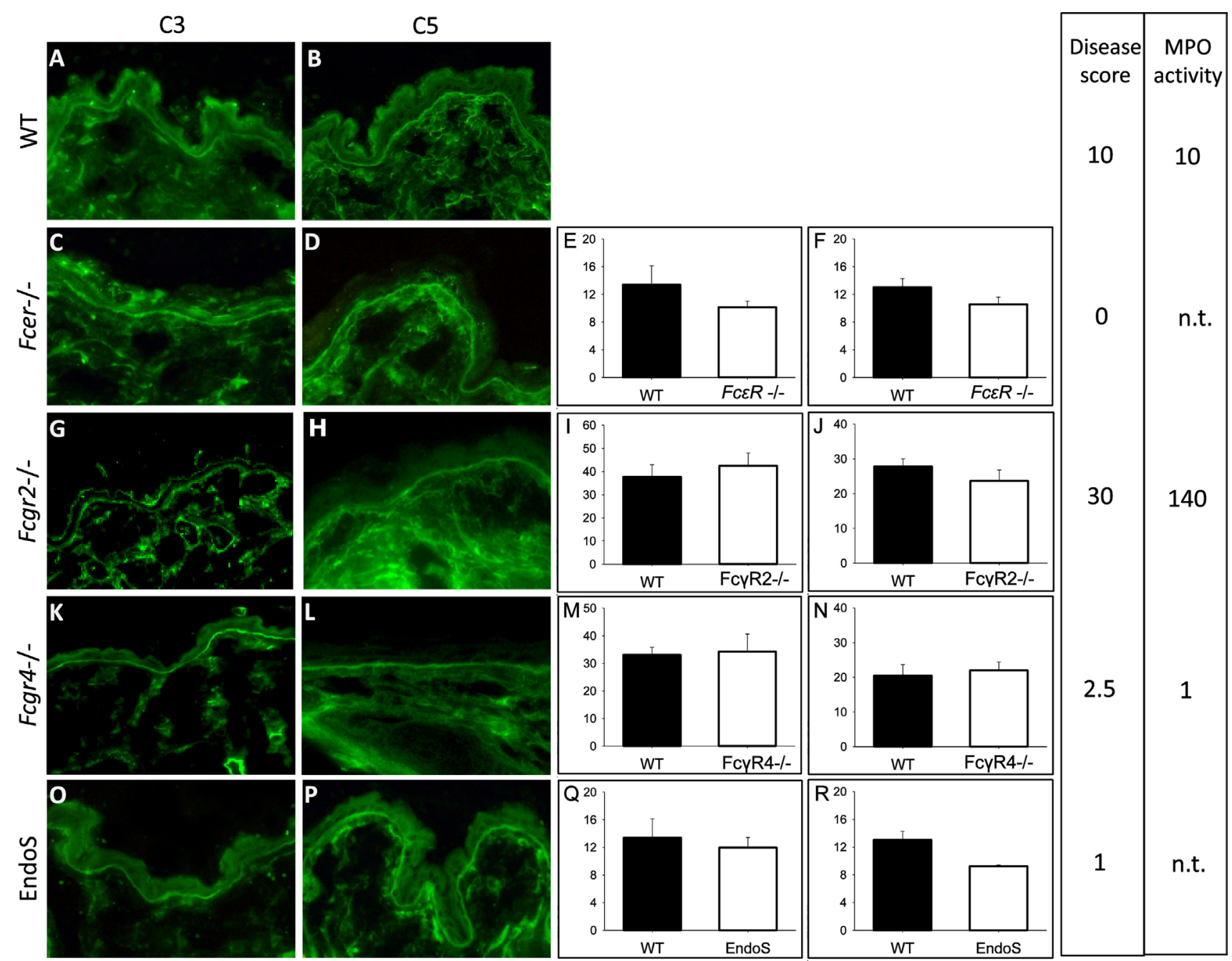

FIGURE 1 | Complement activation at the dermal-epidermal junction (DEJ) is not related to the extent of clinical disease in experimental bullous pemphigoid. The intensity of C3 (E,I,M,Q) and C5 deposition (F,J,N,R) at the DEJ did not differ between wild-type (WT; A,B) mice, mice deficient of the FcR $\left[\right.$ [Fcer ${ }^{-1}$; (C,D)], FC $\gamma$ RIIB

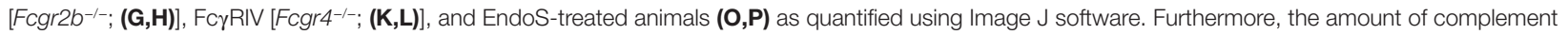
deposition was not reflected by the extent of skin lesions/disease score and the myeloperoxidase (MPO) activity determined in ear skin. Data for disease activity were assembled from different experiments with five mice in each group done at different time points (17). A and B are representative pictures selected from one of the experiments. For direct comparison, disease activity and MPO activity are indicated in arbitrary units related to the mean clinical score and MPO activity in WT animals in each experiment set to 10. n.t., not tested.

\section{Complement Activation Is Important, but Not a Prerequisite for the Development of Skin Lesions}

$C 5^{-/-}$and corresponding wild-type mice were injected six times with 5,10 , and $15 \mathrm{mg}$ of pathogenic anti-Col17 IgG, respectively (each group, $n=5$ ). All mice developed cutaneous BP lesions. Disease activity in $\mathrm{C5}^{-/-}$mice was reduced to between 36 and $54 \%$ compared to corresponding wild-type animals independent of the injected IgG concentration (30 mg IgG, $p=0.004$; $60 \mathrm{mg} \mathrm{IgG}, p=0.013$; $90 \mathrm{mg}$ IgG, $p \leq 0.001$; Figure 2). While the disease activity was clearly dependent on the amount of injected anti-Col17 IgG ( $p=0.025$; Figures 2A,B), the extent of disease reduction in $C 5^{-1-}$ mice in relation to wild-type animals was independent of the anti-Col17 IgG dose (Figures 2A,B). The
MPO reactivity, corresponding to the magnitude of myeloid cell infiltration, in the ears was notably higher in wild-type compared to $C 5^{-1-}$ mice $(p<0.001$; Figure $2 J)$. In contrast, no difference in the linear deposits of IgG at the DEJ by direct IF microscopy of perilesional biopsies taken at day 12 was seen between wild-type and $C 5^{-/-}$mice $(p=0.413$; Figures $2 \mathrm{G}, \mathbf{I})$.

\section{C5aR1 Mediates the Pathogenic Effect of Anti-Col17 IgG-Induced C5 while C5aR2 Is Protective}

$C 5 \operatorname{arr}^{-/-}(n=10)$ and C5ar2 ${ }^{-/-}$mice $(n=15)$ as well as the corresponding wild-type animals $(n=10$ and $n=18)$ were injected six times with $5 \mathrm{mg}$ of pathogenic anti-Col17 IgG in two independent experiments. $\mathrm{C} \mathrm{ar} 1^{-1-}$ mice developed less disease compared 
A
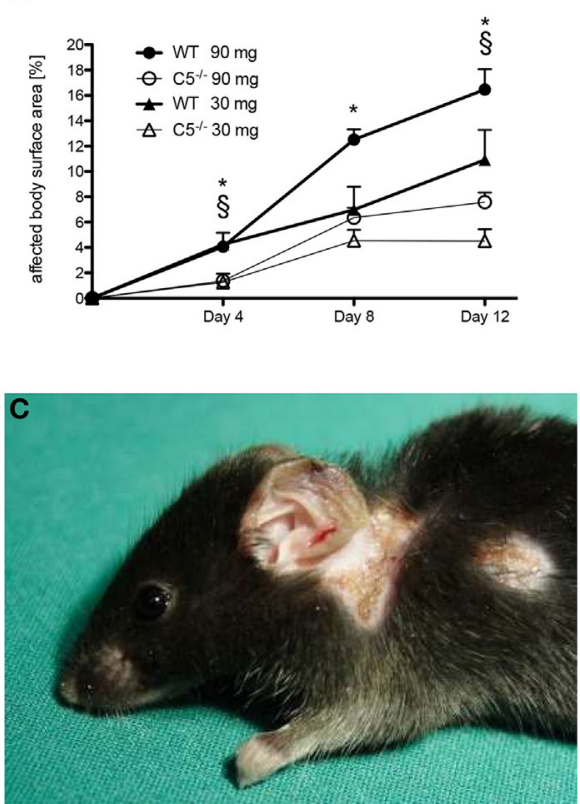

E
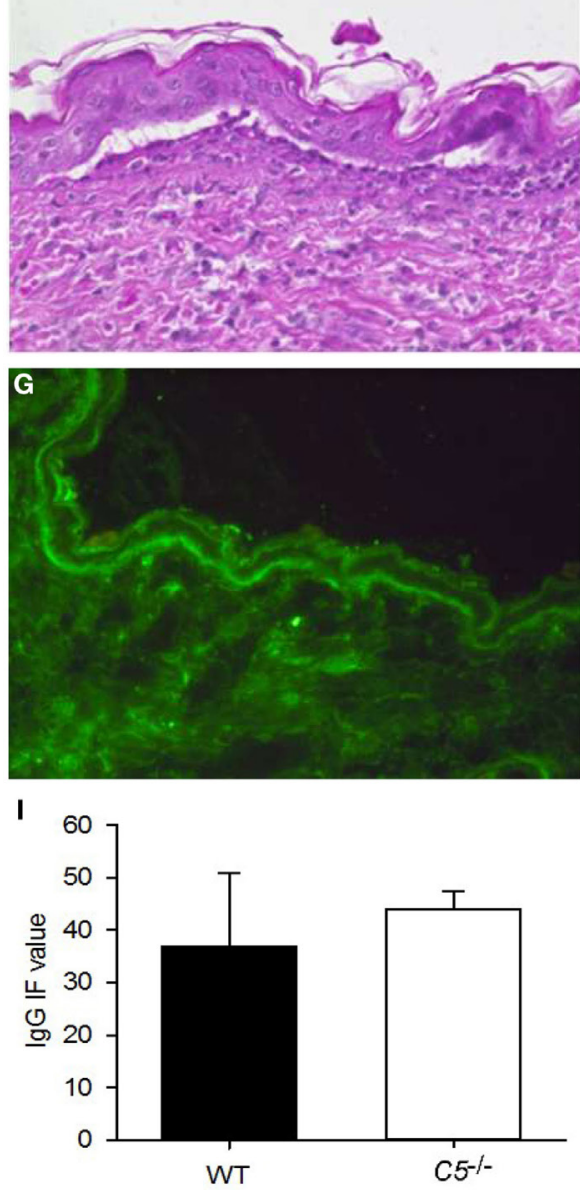
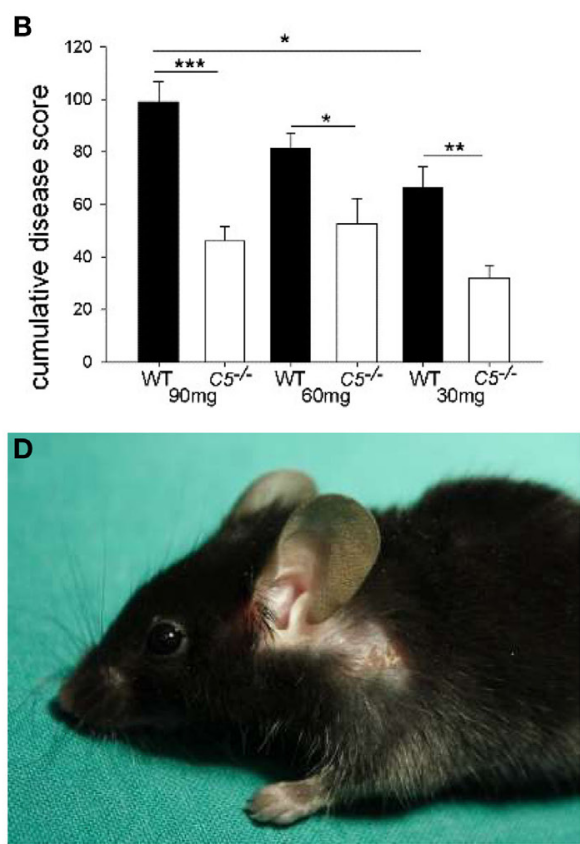

$\mathbf{F}$
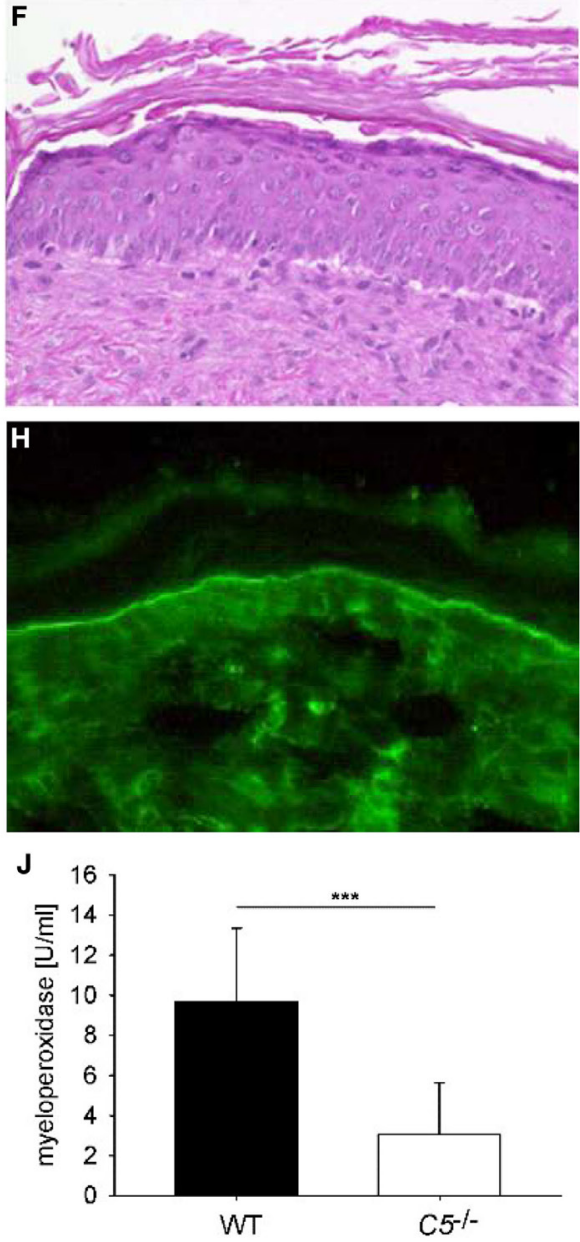

FIGURE 2 | Continued 
FIGURE 2 | Anti-mCol17 lgG induces cutaneous disease in complement five-deficient (C5-/-) mice. C5 $5^{-/-}(n=5)$ and wild-type $($ WT; $n=5)$ mice were injected with three different doses of anti-mCol17 lgG (six times 5 mg, six times $10 \mathrm{mg}$, and six times $15 \mathrm{mg}$ ) every second day. Disease activity was measured as percentage of affected body surface area on days 4,8 , and 12 (A). The overall clinical activity of all mice in each group was derived from the area under the curve of the affected body surface and expressed as cumulative score. The cumulative score of C5 ${ }^{-1-}$ was about half compared to WT mice independent of the injected amount of anti-Col17 lgG (B). Infiltration of neutrophils in lesional ear skin as reflected by myeloperoxidase activity ( $\mathbf{J}$ ) was significantly reduced in C5 ${ }^{-/-}$compared to WT animals. In contrast, deposits of lgG at the dermal-epidermal junction did not differ between WT and C5 $5^{-/-}$mice (I). Representative pictures of clinical lesions (C,D), lesional histopathology (E,F), and lgG deposits by direct immunofluorescence microscopy (G,H) are shown in WT (C,E,G) and C5 ${ }^{-/-}$mice (D,F,H). ${ }^{\star} p<0.05,90$ mg groups; ${ }^{\S} p<0.05,30$ mg groups $(\mathbf{A}) .{ }^{*} p<0.05 ;{ }^{\star *} p<0.01 ;{ }^{* \star *} p<0.001$ (B, J).

to wild-type mice. Differences were detected between the two groups when the whole observation period was considered $(p=0.001)$ as well as individually on days $4(p<0.001)$ and 12 $(p=0.007$; Figures $3 \mathrm{~A}-\mathrm{E})$. The difference between the two groups increased over time ( $p$ for interaction $=0.005$ ). In contrast, in $C 5 a r 2^{-1-}$ mice, more skin lesions developed as compared to wildtype mice (whole observation period, $p=0.004$ ) as well as on days $4(p=0.018), 8(p=0.033)$, and $12(p=0.046$; Figures $3 \mathbf{F}-\mathbf{J})$. The difference between the two groups also increased over time ( $p$ for interaction $=0.017$ ). The mean infiltration of neutrophils as determined by MPO activity in the right ears appeared to be lower in $\mathrm{C} \mathrm{arl}^{-/-}$mice (although statistical significance was not reached with $p=0.052$ ) but not in $C 5 a r 2^{-1}$ animals compared to wild-type mice ( $p=0.178$; Figures $3 \mathrm{~K}, \mathrm{~L})$.

\section{Pharmacological Inhibition of C5aR Reduces Skin Lesions in a Prophylactic but Not in a Therapeutic Approach}

To assess the potential of $\mathrm{C} 5 \mathrm{aR} 1$ as a new therapeutic target in $\mathrm{BP}, \mathrm{C} 57 \mathrm{Bl} / 6$ mice were injected six times with $5 \mathrm{mg}$ of anti-Col17 IgG and received daily injections of $200 \mu \mathrm{g}$ of the C5aR1 antagonist PMX53 (days $0-11 ; n=11)$ and PBS $(n=13)$, respectively (prophylactic setting). In the PMX53-injected mice, skin lesions, disease and MPO activity in the right ears were less increased compared to control mice (although statistical significance was not reached with $p=0.082$ and $p=0.068$; Figures 4A,C). In a quasitherapeutic approach, daily injections of PMX53 at individual doses of $200 \mu \mathrm{g}$ were given at day 4, when first skin lesions had already developed, and continued until day 11. In this setting, disease activity and neutrophil infiltration did not differ between PMX53-injected and control mice over time $(p=0.952$, $p=0.720$; Figures 4B,D).

\section{Complement Is Not a Main Driver of Immune Complex-Mediated ROS Release from Neutrophils}

The role of complement as a mediator of ROS release from neutrophils in response to immune complexes of recombinant $\mathrm{mCol17} \mathrm{NC15A}$ and anti-mCol17 IgG was explored by the use of a previously described in vitro assay $(25,26)$. In the first set of experiments, immune complexes were incubated in the presence of normal mouse serum and heat inactivated mouse serum, respectively, before mouse neutrophils were added. While the ROS release increased in response to the addition of normal mouse serum at different dilutions $(p<0.001)$, no difference in ROS release was observed between incubation with normal mouse serum and heat inactivated serum $(p=0.229, p=548$, $p=0.345$; Figure 5A).

In the next set of experiments, we tested the involvement of $\mathrm{C} 5 \mathrm{aR} 1$ and $\mathrm{C} 5 \mathrm{aR} 2$ in driving the ROS release using neutrophils from wild-type, $\mathrm{C}_{5} \mathrm{ar}^{-/-}$, and $\mathrm{C} 5 \mathrm{ar} 2^{-/-}$mice. While clear differences were seen between immune complexes and antigen alone using wild-type, $C 5 a r 1^{-/-}$, and C5ar2 $2^{-/-}$neutrophils $(p=0.020$, $p=0.005$, and $p=0.008$ ), no statistical difference was observed between the ROS release of wild-type neutrophils and neutrophils from $C 5 \mathrm{arl}^{-/-}$and C5ar2 ${ }^{-/-}$mice $(p=0.655, p=0.554$; Figure 5B). In contrast, when neutrophils from $\mathrm{Fcer}^{-/-}$mice that lack the activating $\gamma$-chain of the Fc receptor were used, the ROS release was nearly abrogated compared to the use of wild-type neutrophils ( $p<0.001$; Figure 5C).

\section{The Migration of $\mathrm{C} \mathrm{ar1}^{-/-}$but Not C5ar2 ${ }^{-/-}$ Neutrophils Is Greatly Impaired}

To test the hypothesis that neutrophil chemotaxis can be mediated by $\mathrm{C} 5 \mathrm{aRs}$ in vitro, migration of wild-type neutrophils and neutrophils from $\mathrm{C}_{5} \mathrm{arl}^{-/-}$and $\mathrm{C}^{-1} \mathrm{ar}^{-/-}$mice toward C5a was quantified using a modified Boyden chamber. $\mathrm{C}^{2} \mathrm{arl}^{-/-}$neutrophils showed a significantly lower migration potential compared to wild-type cells ( $p<0.001$; Figure 5D). In contrast, no difference was seen between the migration of wild-type and C5ar2-/neutrophils ( $p=0.901$; Figure 5D).

\section{DISCUSSION}

Complement can be activated by three pathways, the classical, the alternative, and the lectin pathway $(30,31)$. Activation of the complement system by any of the three pathways leads to activation of $\mathrm{C} 3$ and subsequently, to activation of C5 to form C5a and C5b. C5a is crucially involved in the host defense, immune surveillance, and tissue homeostasis $(32,33)$. However, C5a can also be the driver in autoimmune $(34,35)$ and other inflammatory diseases (36). Strong and prolonged activation of C5a leads to downregulation of immune responses in leukocytes, but has opposing effects in other cell types (37). This controversial function of $\mathrm{C} 5 \mathrm{a}$ is often explained by the differential expression of the two C5aRs, C5aR1 and C5aR2. While signaling through $\mathrm{C} 5 \mathrm{aR} 1$ is well characterized and reported to induce chemotaxis, mediate interaction with toll-like receptors, and regulate FcyR expression $(30,31,38,39)$, the functional properties of C5aR2 are still elusive, and both anti- and proinflammatory responses have been reported (37, 40-46).

In BP, like in various other autoantibody-mediated diseases including anti-neutrophil cytoplasmatic autoantibody-associated 

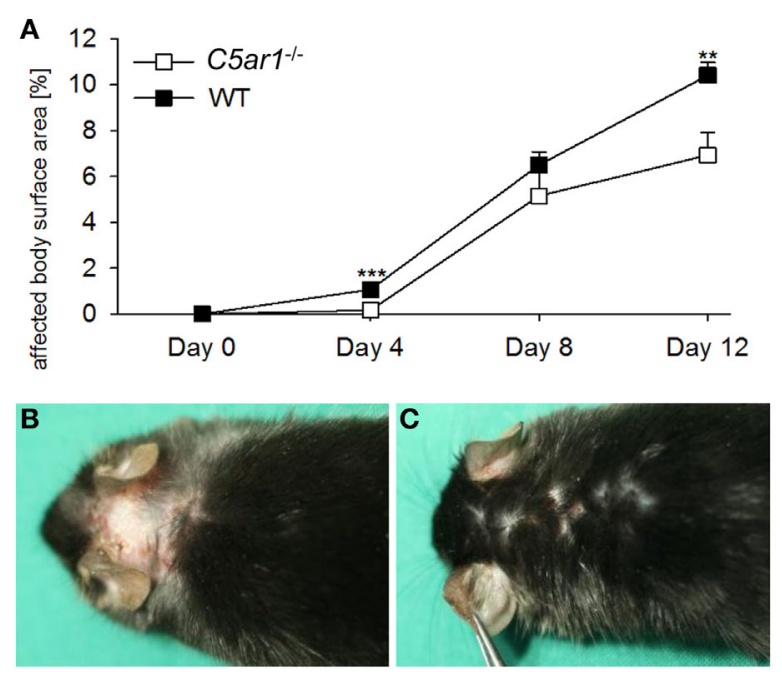

D

E

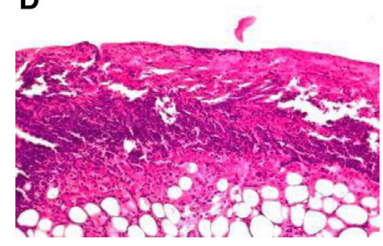

$\mathbf{F}$
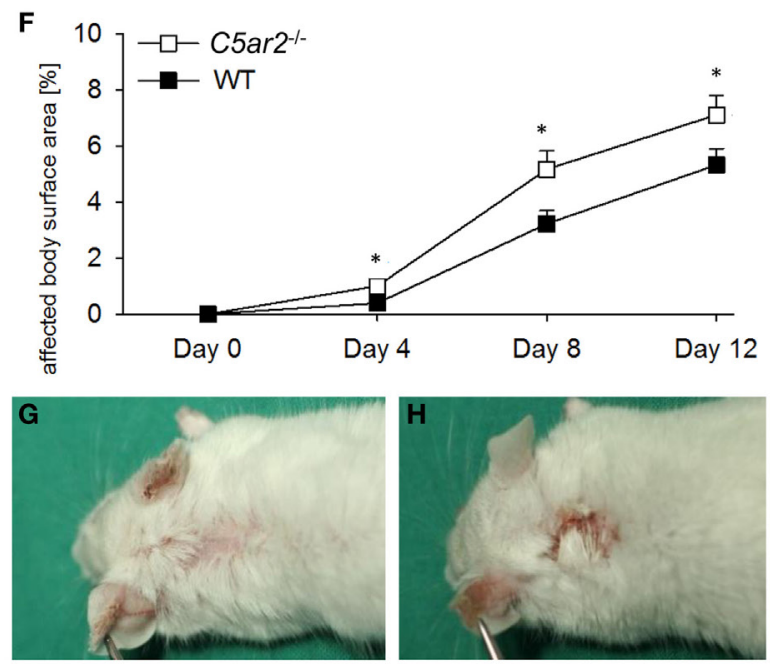

I
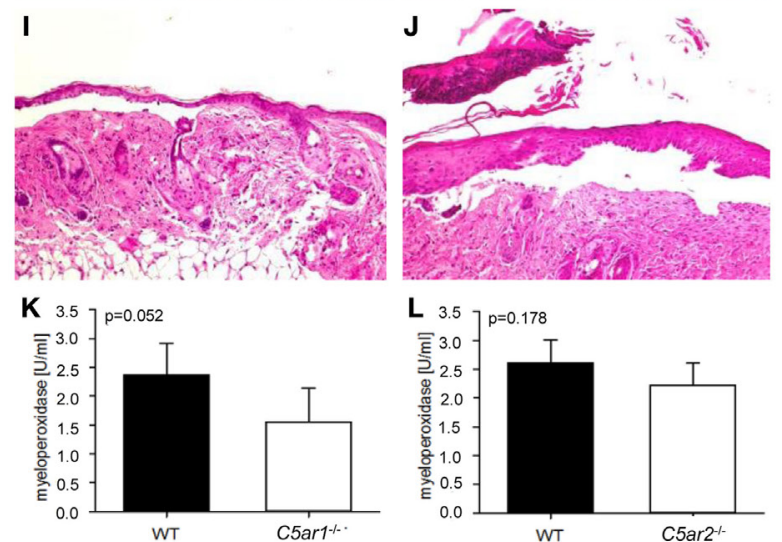

L 3.5$]^{\mathrm{p}=0.178}$

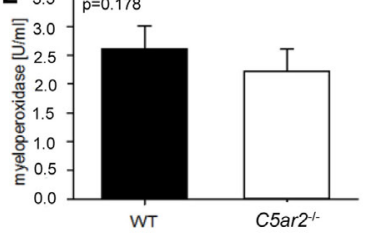

FIGURE 3 | Continued
FIGURE 3 | C5a receptor 1 (C5aR1) mediates tissue destruction by anti-mCol17 IgG, while C5aR2 is protective. Injection of anti-mCol17 IgG in C5ar1-deficient (C5ar1 $\left.{ }^{-/-}\right)$mice $(n=10)$ resulted in significantly less bullous pemphigoid skin lesions compared to wild-type (WT) mice [ $n=10$; (A)]. In contrast, injection of anti-mCol17 lgG in C5ar2-/- mice $(n=15)$ led to a higher disease activity compared to WT mice $[n=18$; $(\mathbf{F})]$. Representative pictures of clinical $(\mathbf{B}, \mathbf{C}, \mathbf{G}, \mathbf{H})$ and histopathological lesions $(\mathbf{D}, \mathbf{E}, \mathbf{I}, \mathbf{J})$ are shown in C5ar1-/- (C,E), C5ar2 ${ }^{-/-} \mathbf{( H , D )}$, and WT mice (B,D,G,I). Infiltration of neutrophils in skin lesions, as reflected by myeoloperoxidase activity, was

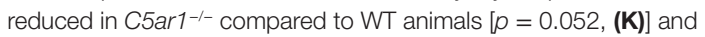

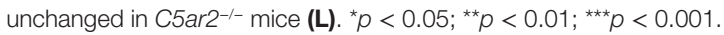

vasculitides, systemic lupus erythematosus, rheumatoid arthritis, antiglomerular basement membrane disease, epidermolysis bullosa acquisita, and antilaminin 332 mucous membrane pemphigoid, complement activation is regarded as pivotal for lesion formation (11-14, 19, 34, 47-51). The traditional view derived from the neonatal mouse model of BP that complement activation is required for lesion formation has recently been challenged by the observation that $\mathrm{F}\left(\mathrm{ab}^{\prime}\right)_{2}$ fragments of anti-hColl7 IgG also induced BP-like skin lesions in neonatal COL17-humanized mice (15). Complement-independent pathogenic effects of anti-Coll7 antibodies have also been demonstrated in vitro when treatment of cultured keratinocytes with anti-Col17 antibodies led to the secretion of IL- 6 and IL-8 as well as reduced cell surface expression of Col17 followed by weakened attachment of keratinocytes (52-54).

We have recently established a novel experimental model of $\mathrm{BP}$ in adult mice that overcame some of the shortcomings of the neonatal models, e.g., lesions develop spontaneously over some days without the application of friction (17). Importantly, in contrast to the neonatal mouse models, the novel adult mouse model was shown to be suitable to analyze the potential of antiinflammatory agents in a quasi-therapeutic setting, i.e., in mice with already established skin lesions (17).

The two aims of the current study were therefore to clarify the pathophysiological role of complement activation by the use of the recently established BP model in adult mice and explore the therapeutic potential of complement inhibition for BP. The therapeutic potential of $\mathrm{C} 5 \mathrm{aR} 1$ targeting is of particular relevance given the growing list of complement inhibitors that are in phase II and III clinical trials (16) and the urgent need for more specific and safe treatment options in BP. So far, long-term use of superpotent topical or oral corticosteroids is the therapeutic backbone of BP, often supplemented with potentially steroid-sparing agents such as azathioprine, methotrexate, dapsone, or doxycycline (55-58).

In previous experiments, we have shown that mice lacking the $\mathrm{Fc \gamma R}\left(\mathrm{Fcer}^{--}\right)$were completely protected from the development of cutaneous disease after injection of anti-Col17, while skin lesions were significantly more extended in $\mathrm{Fcgr} \mathrm{b}^{-/}$animals (17). Identical findings were also made in an adult antibody transfer-induced model of inflammatory epidermolysis bullosa acquisita (24). When wild-type mice were injected with anti-Col17 IgG pretreated with EndoS, an endoglycosidase that specifically hydrolyzes the N-linked glycan on IgG heavy chains, only few skin lesions occurred $(21,29)$. Hydrolysis of IgG glycan has previously been shown to reduce the binding to activating Fc $\gamma$ Rs and thus the proinflammatory effect of autoantibodies (21). When we 

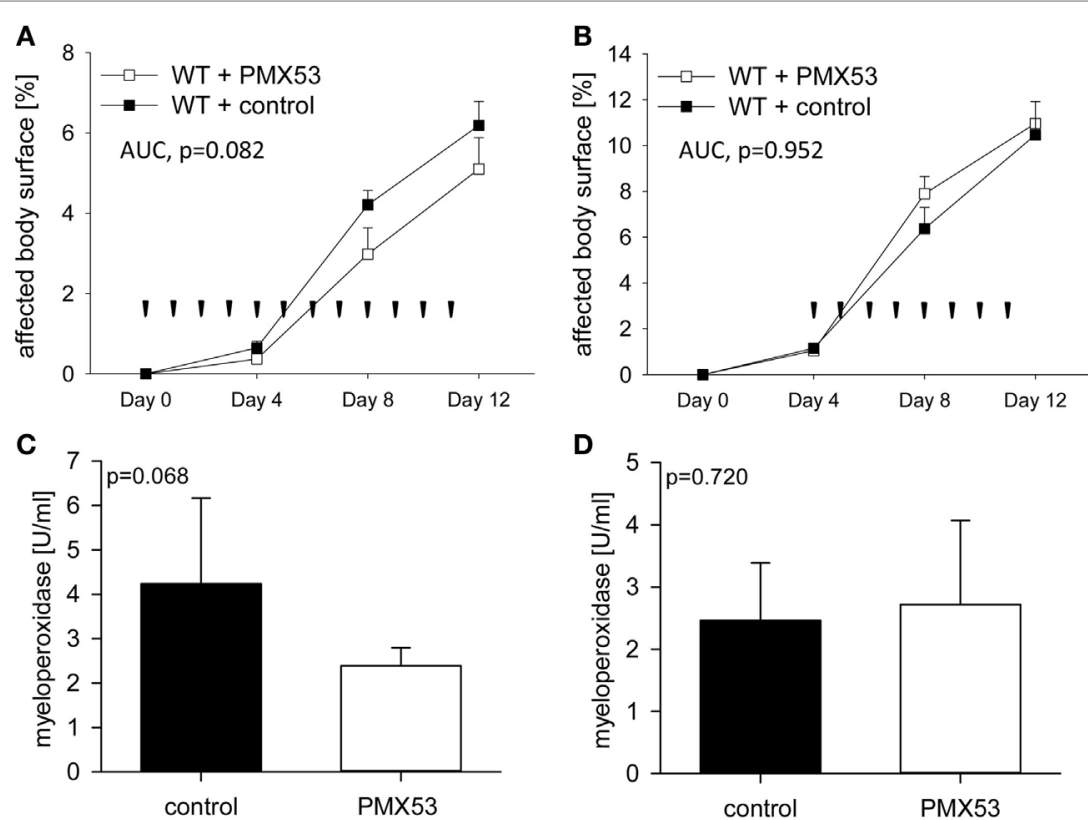

FIGURE 4 | Pharmacological inhibition of C5a receptor 1 (C5aR1) reduces clinical disease in experimental bullous pemphigoid (BP) only in a prophylactic approach but not when skin lesions have already developed. When C57BL/6 mice were injected daily with the C5aR1 inhibitor PMX53 $(n=11)$ and PBS $(n=13)$, respectively, in parallel with injection of anti-mCol17 IgG on days 0, 2, 4, 6, 8, and 10, less BP lesions were observed in PMX53-treated mice (A). In contrast, when PMX53 and PBS injections were started on day 4, the extent of clinical disease did not differ between the PMX53-injected and the control mice (B). Arrow heads indicate injections of PMX53 and PBS, respectively. Infiltration of neutrophils in skin lesions, as reflected by myeloperoxidase activity, was reduced in the prophylactic (C) but not in the therapeutic approach (D).

here quantified the intensity of $\mathrm{C} 3$ and $\mathrm{C} 5$ deposition at the DEJ at the end of the experiment on day 12, no differences between wild-type animals and mice deficient for the Fc $\gamma$ R, Fc $\gamma$ RIV, and Fc $\gamma$ RIIB, respectively, and mice injected with EndoS-pretreated anti-Col17 IgG were seen. In contrast, in the same mice, significant differences in both extent of skin lesions (17) and MPO activity in ear skin, which paralleled disease activity, were seen.

A somehow similar observation was made in pemphigus, an autoimmune blistering disease characterized by autoantibodies against structural components of the desmosome, desmoglein 1 and $3(59,60)$. In pemphigus, complement deposits in the skin/ epithelium is found in almost all patients, however, complement activation is not required for lesion formation (61). Our observations that complement activation at the DEJ appeared to be unrelated to the extent of clinical disease prompted us to further explore the role of complement in this novel model of experimental BP.

We then asked the question whether complement activation is a prerequisite for the induction of clinical disease in this model. When $\mathrm{C5}^{-/-}$mice were injected with different amounts of anti-Col17 IgG, the extent of skin lesions decreased by about $50 \%$ compared to wild-type animals. Of note, the impact of C5 was independent of the anti-Col17 IgG dose. This finding is in contrast to previous findings in experimental neonatal BP in which $\mathrm{C}^{-1-}$ mice were completely resistant to the pathogenic effect of anti-Col17 IgG (11). In fact, with $\mathrm{C}^{-/-}$and anti-C1qantibody-injected mice being completely protected and factor $\mathrm{B}(\mathrm{CFB})^{-/-}$mice being partly protected, both the classical and, to a lesser extent, the alternative pathway were shown to be crucial in this model (12). The importance of the classical complement pathway was also elegantly demonstrated in the Col17-humanized neonatal mouse model. Neonatal Col1 $7^{\mathrm{m}-1-\mathrm{h}+}$ mice injected with a monoclonal anti-human Col17 IgG1 antibody that was mutated at the $\mathrm{C} 1 \mathrm{q}$ binding site developed less pathogenic activity compared to the unmutated antihuman Col17 IgG1-injected animals (14).

More recently, similar to our model, complement-independent pathogenic effects of anti-Col17 IgG were shown in neonatal Col17-humanized mice when $\mathrm{F}\left(\mathrm{ab}^{\prime}\right)_{2}$ fragments of anti-hCol17 IgG and anti-hCol17 IgG4, which do not activate complement at the DEJ, induced skin blistering $(15,62)$. In line, BP patients with predominant IgG autoantibodies and no C3 deposition at the DEJ have been described, and in $15-20 \%$ of BP patients, no C3 deposits along the DEJ can be detected $(63,64)$.

In subsequent experiments, we dissected the role of the two $\mathrm{C} 5 \mathrm{aRs}$ downstream of $\mathrm{C} 5$ in the pathogenesis of BP and addressed the question at what stage of the disease complement activation may be important. Using knock-out mice and a specific inhibitor, we found that C5aR1 mediated the pathogenic effect of C5a, while C5aR2 appeared to protect from BP skin lesions. This is line with previous reports suggesting an anti-inflammatory role for C5aR2 counter-regulating pro-inflammatory properties of C5aR1 $(42,43)$. Given that the effect of C5-deficiency was more pronounced than that of C5R1-deciciency may suggest that in addition to $\mathrm{C} 5 \mathrm{aR} 1$ and $\mathrm{C} 5 \mathrm{aR} 2$, the membrane attack complex may exert pro-inflammatory effects. Indeed, sublytic amounts 

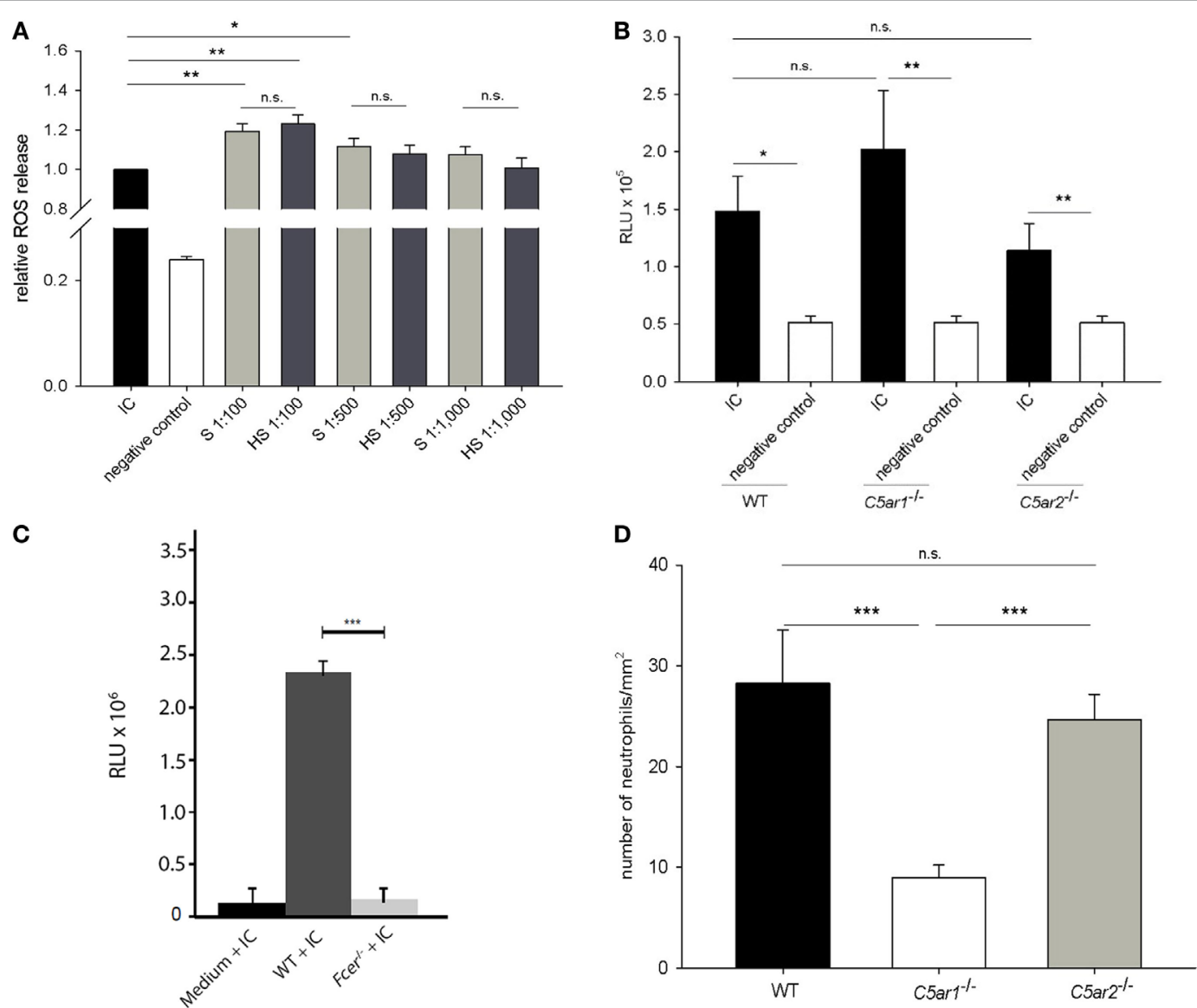

FIGURE $\mathbf{5}$ | While complement activation is not the main driver of immune complex-mediated release of reactive oxygen species (ROS) from mouse neutrophils, $\mathrm{C} 5 \mathrm{a}$ is a strong chemoattractant for neutrophils. Neutrophils isolated from the bone marrow of C57BI/6 mice were incubated with immune complexes of mCol17 and anti-mCol17 lgG. Addition of serum (S) and heat-inactivated serum (HS), respectively, led to significantly higher ROS releases compared to stimulation with immune complexes alone, while no difference between incubation with S and HS was seen (A). When neutrophils from C57BL/6 wild-type (WT), C5ar1 ${ }^{-/-}$, and C5ar2 ${ }^{-/-}$mice were incubated with immune complexes, a significantly higher ROS release was seen compared to incubation with the collagen alone. No differences were observed between the ROS release of wild-type, C5ar1 $1^{-/}$, and C5ar2 ${ }^{-/-}$neutrophils in response to immune complexes (B). In contrast, in neutrophils that lack the activating $\gamma$-chain of the Fc receptor $\left(F_{c e} r^{--}\right)$the ROS release was greatly reduced compared to WT cells (C). Migration of bone marrow-derived neutrophils from C5ar $1^{-1-}$ mice toward recombinant C5a was significantly lower compared to neutrophils from both C57BL/6 WT and C5ar2 ${ }^{-/-}$mice. No difference was seen between the migration of ${\mathrm{C} 5 a r 2^{-/-}}$and WT neutrophils. Depicted is the number of migrated cells per $\mathrm{mm}^{2}$ as calculated from the evaluation of ten high-power fields. PBS-treated cells served as control (not shown). Means of triplicate samples are shown (D). n.s., not significant; ${ }^{*} p<0.05 ;{ }^{* *} p<0.01 ;{ }^{* \star *} p<0.001$.

can activate the NLRP3 inflammasome (65), a mechanism that may also apply to the activation of effector cells in BP.

When we addressed the second aim of our study, i.e., the pharmacological inhibition of C5aR1, we observed reduced skin lesions after the prophylactic application of the C5aR1 inhibitor PMX53. However, this effect was weaker than that obtained with $C 5 a r r^{-1-}$ mice. This discrepancy may be explained by an insufficient dosing or an incomplete silencing of C5aR1 by PMX. When PMX was applied in a quasi-therapeutic setting, i.e., when first skin lesions had already developed, no effect on both skin lesions and neutrophil infiltration in the dermis was seen. Combined with our results in the first set of experiments that had revealed strong complement activation along the DEJ during the course of the disease (at day 12) irrespective of the disease severity, we hypothesized that complement activation in the skin may be relevant in the early disease phase, while in established disease, complement-mediated tissue destruction may be redundant.

This hypothesis was addressed applying neutrophils, the main effector cell of tissue destruction in experimental murine $\mathrm{BP}$, in two in vitro models. The migration assay toward C5a reflects an early disease time point when $\mathrm{C} 5 \mathrm{a}$ is released in close vicinity of the DEJ following the attachment of anti-Col17 IgG to Col17. The ROS release assay mimics a later time point when leukocytes have already attached along the DEJ. While migration was drastically reduced in $C 5 a r 1^{-1-}$ neutrophils, no difference in the ROS release of wild-type leukocytes between stimulation with serum and heat-inactivated serum was seen. Furthermore, no significant differences in the ROS release of wild-type and $\mathrm{C}_{\mathrm{arr}} \mathrm{C}^{-/}$and $\mathrm{C}_{5} \mathrm{ar}^{-/-}$neutrophils were observed. In contrast, the ROS release was nearly abrogated in neutrophils from mice that lack the activating $\gamma$-chain of the Fc receptor compared to 
wild-type neutrophils. These results suggest that complement activation may be of particular importance in the early phase of the disease when neutrophils are attracted to the DEJ. In fact, C5a may lead to an increased expression of adhesion molecules on endothelial cells and neutrophils and can delay apoptosis $(31,66)$. Due to logistical constrains, cells from $C 5 a r 2^{-1-}$ mice on a C57BL/ 6 background were used for the in vitro studies. Since in previous experiments with the antibody transfer-induced mouse model of BP both wild-type and Fcgrl ${ }^{-/-}$mice on a Balb/c background developed the same extent of clinical disease compared to animals on a C57BL/ 6 background (17), we believe that no principle differences between $C 5 a r 2^{-1-}$ mice on a C57BL/6 and $\mathrm{Balb} / \mathrm{c}$ background in our in vitro studies could be expected.

Neutrophils have been identified as drivers of tissue destruction in the different mouse models of $\mathrm{BP}(6-8,11,18)$. The view that $\mathrm{C} 5 \mathrm{aR} 1$ is important during the early phase of the disease is supported by the observation that C5aR expression on mast cells, a cell resident in the dermis, is essential for blister formation (13). Once the skin inflammation has fully developed, release of ROS and proteases from neutrophils and macrophages may become independent of complement and may be mainly mediated via Fc $\gamma$ Rs. This hypothesis is corroborated by previous findings in $C 4^{-1-}$ neonatal mice, that, although completely resistant against the pathogenic effect of anti-Col17 IgG, developed clinical blisters after injection of the neutrophil attractant IL-8 or neutrophils in the skin (12). The mechanism underlying the C5aR2-mediated anti-inflammatory effect in experimental BP requires further investigations. Two peptides with C5aR2-agonistic effect have recently been identified (37) and will facilitate this endeavor.

\section{REFERENCES}

1. Langan SM, Smeeth L, Hubbard R, Fleming KM, Smith CJ, West J. Bullous pemphigoid and pemphigus vulgaris - incidence and mortality in the UK: population based cohort study. BMJ (2008) 337:a180. doi:10.1136/bmj.a180

2. Joly P, Baricault S, Sparsa A, Bernard P, Bedane C, Duvert-Lehembre S, et al. Incidence and mortality of bullous pemphigoid in France. J Invest Dermatol (2012) 132(8):1998-2004. doi:10.1038/jid.2012.35

3. Schmidt E, Zillikens D. Pemphigoid diseases. Lancet (2013) 381(9863):320-32. doi:10.1016/S0140-6736(12)61140-4

4. Hubner F, Recke A, Zillikens D, Linder R, Schmidt E. Prevalence and age distribution of pemphigus and pemphigoid diseases in Germany. Invest Dermatol (2016) 136(12):2495-8. doi:10.1016/j.jid.2016.07.013

5. Zillikens D, Rose PA, Balding SD, Liu Z, Olague-Marchan M, Diaz LA, et al. Tight clustering of extracellular BP180 epitopes recognized by bullous pemphigoid autoantibodies. J Invest Dermatol (1997) 109(4):573-9. doi:10.1111/1523-1747.ep12337492

6. Nishie W, Sawamura D, Goto M, Ito K, Shibaki A, McMillan JR, et al. Humanization of autoantigen. Nat Med (2007) 13(3):378-83. doi:10.1038/ nm1496

7. Ujiie H, Shibaki A, Nishie W, Sawamura D, Wang G, Tateishi Y, et al. A novel active mouse model for bullous pemphigoid targeting humanized pathogenic antigen. J Immunol (2010) 184(4):2166-74. doi:10.4049/jimmunol.0903101

8. Liu Z, Diaz LA, Troy JL, Taylor AF, Emery DJ, Fairley JA, et al. A passive transfer model of the organ-specific autoimmune disease, bullous pemphigoid, using antibodies generated against the hemidesmosomal antigen, BP180. J Clin Invest (1993) 92(5):2480-8. doi:10.1172/JCI116856

9. Yamamoto K, Inoue N, Masuda R, Fujimori A, Saito T, Imajoh-Ohmi S, et al. Cloning of hamster type XVII collagen cDNA, and pathogenesis of anti-type

\section{ETHICS STATEMENT}

Animal experiments were approved by the Animal Care and Use Committee of Schleswig-Holstein (Kiel, Germany; 21-2/11, 40-3/15) and performed by certified personnel.

\section{AUTHOR CONTRIBUTIONS}

TB, MH, JT, ST, FSS, and EH have performed the experiments and analyzed the data. RL, DZ, JK, CK, and ES have designed the work and interpreted the data. FS and ST generated the figures. IK has interpreted the data and performed the statistical analyses. CK and ES have, in addition, overseen the experimental work and written the manuscript. All authors have approved the final version of the manuscript.

\section{ACKNOWLEDGMENTS}

We thank Rebecca Cames for excellent technical assistance. We are grateful to Dr. Trent Woodruff, University of Queensland, Brisbane, Australia, for providing PMX53.

\section{FUNDING}

This work was supported by grants from the Excellence Cluster "Inflammation at Interfaces" (EXC306/2), the University of Lübeck, the Research Training Group 1727 Modulation of Autoimmunity (GRK1727/1), and the Clinical Research Unit 303 Pemphigoid Diseases.
XVII collagen antibody and complement in hamster bullous pemphigoid. J Invest Dermatol (2002) 118(3):485-92. doi:10.1046/j.0022-202x.2001.01683.x

10. Leighty L, Li N, Diaz LA, Liu Z. Experimental models for the autoimmune and inflammatory blistering disease, bullous pemphigoid. Arch Dermatol Res (2007) 299(9):417-22. doi:10.1007/s00403-007-0790-5

11. Liu Z, Giudice GJ, Swartz SJ, Fairley JA, Till GO, Troy JL, et al. The role of complement in experimental bullous pemphigoid. JClin Invest (1995) 95(4):1539-44. doi:10.1172/JCI117826

12. Nelson KC, Zhao M, Schroeder PR, Li N, Wetsel RA, Diaz LA, et al. Role of different pathways of the complement cascade in experimental bullous pemphigoid. J Clin Invest (2006) 116(11):2892-900. doi:10.1172/JCI17891

13. Heimbach L, Li Z, Berkowitz P, Zhao M, Li N, Rubenstein DS, et al. The C5a receptor on mast cells is critical for the autoimmune skin-blistering disease bullous pemphigoid. J Biol Chem (2011) 286(17):15003-9. doi:10.1074/jbc. M111.221036

14. Li Q, Ujiie H, Shibaki A, Wang G, Moriuchi R, Qiao HJ, et al. Human IgG1 monoclonal antibody against human collagen 17 noncollagenous $16 \mathrm{~A}$ domain induces blisters via complement activation in experimental bullous pemphigoid model. J Immunol (2010) 185(12):7746-55. doi:10.4049/ jimmunol.1000667

15. Natsuga K, Nishie W, Shinkuma S, Ujiie H, Nishimura M, Sawamura D, et al. Antibodies to pathogenic epitopes on type XVII collagen cause skin fragility in a complement-dependent and -independent manner. J Immunol (2012) 188(11):5792-9. doi:10.4049/jimmunol.1003402

16. Morgan BP, Harris CL. Complement, a target for therapy in inflammatory and degenerative diseases. Nat Rev Drug Discov (2015) 14(12):857-77. doi:10.1038/nrd4657

17. Schulze FS, Beckmann T, Nimmerjahn F, Ishiko A, Collin M, Kohl J, et al. Fcgamma receptors III and IV mediate tissue destruction in a novel adult 
mouse model of bullous pemphigoid. Am J Pathol (2014) 184(8):2185-96. doi:10.1016/j.ajpath.2014.05.007

18. Hirose M, Recke A, Beckmann T, Shimizu A, Ishiko A, Bieber K, et al. Repetitive immunization breaks tolerance to type XVII collagen and leads to bullous pemphigoid in mice. J Immunol (2011) 187(3):1176-83. doi:10.4049/ jimmunol.1100596

19. Sitaru C, Mihai S, Otto C, Chiriac MT, Hausser I, Dotterweich B, et al. Induction of dermal-epidermal separation in mice by passive transfer of antibodies specific to type VII collagen. J Clin Invest (2005) 115(4):870-8. doi:10.1172/JCI200521386

20. Collin M, Olsen A. EndoS, a novel secreted protein from Streptococcus pyogenes with endoglycosidase activity on human IgG. EMBO J (2001) 20(12): 3046-55. doi:10.1093/emboj/20.12.3046

21. Hirose M, Vafia K, Kalies K, Groth S, Westermann J, Zillikens D, et al. Enzymatic autoantibody glycan hydrolysis alleviates autoimmunity against type VII collagen. J Autoimmun (2012) 39(4):304-14. doi:10.1016/j.jaut.2012. 04.002

22. Bieber $\mathrm{K}, \mathrm{Koga} \mathrm{H}$, Nishie W. In vitro and in vivo models to investigate the pathomechanisms and novel treatments for pemphigoid diseases. Exp Dermatol (2017) 26(12):1163-70. doi:10.1111/exd.13415

23. Hammers CM, Bieber K, Kalies K, Banczyk D, Ellebrecht CT, Ibrahim SM, et al. Complement-fixing anti-type VII collagen antibodies are induced in Th1-polarized lymph nodes of epidermolysis bullosa acquisita-susceptible mice. J Immunol (2011) 187(10):5043-50. doi:10.4049/jimmunol.1100796

24. Kasperkiewicz M, Nimmerjahn F, Wende S, Hirose M, Iwata H, Jonkman MF, et al. Genetic identification and functional validation of FcgammaRIV as key molecule in autoantibody-induced tissue injury. J Pathol (2012) 228(1):8-19. doi:10.1002/path.4023

25. Yu X, Holdorf K, Kasper B, Zillikens D, Ludwig RJ, Petersen F. FcgammaRIIA and FcgammaRIIIB are required for autoantibody-induced tissue damage in experimental human models of bullous pemphigoid. J Invest Dermatol (2010) 130(12):2841-4. doi:10.1038/jid.2010.230

26. Recke A, Vidarsson G, Ludwig RJ, Freitag M, Moller S, Vonthein R, et al. Allelic and copy-number variations of FcgammaRs affect granulocyte function and susceptibility for autoimmune blistering diseases. J Autoimmun (2015) 61:36-44. doi:10.1016/j.jaut.2015.05.004

27. Karsten CM, Laumonnier Y, Kohl J. Functional analysis of C5a effector responses in vitro and in vivo. Methods Mol Biol (2014) 1100:291-304. doi:10.1007/978-1-62703-724-2_23

28. Noguchi K, Gel YR, Brunner E, Konietschke F. nparLD: an R software package for the nonparametric analysis of longitudinal data in factorial experiments. J Stat Softw (2012) 50(12):1-23. doi:10.18637/jss.v050.i12

29. Collin M, Shannon O, Bjorck L. IgG glycan hydrolysis by a bacterial enzyme as a therapy against autoimmune conditions. Proc Natl Acad Sci U S A (2008) 105(11):4265-70. doi:10.1073/pnas.0711271105

30. Ricklin D, Hajishengallis G, Yang K, Lambris JD. Complement: a key system for immune surveillance and homeostasis. Nat Immunol (2010) 11(9): 785-97. doi:10.1038/ni.1923

31. Verschoor A, Karsten CM, Broadley SP, Laumonnier Y, Kohl J. Old dogsnew tricks: immunoregulatory properties of $\mathrm{C} 3$ and $\mathrm{C} 5$ cleavage fragments. Immunol Rev (2016) 274(1):112-26. doi:10.1111/imr.12473

32. Guo RF, Riedemann NC, Ward PA. Role of C5a-C5aR interaction in sepsis. Shock (2004) 21(1):1-7. doi:10.1097/01.shk.0000105502.75189.5e

33. Guo RF, Ward PA. Role of C5a in inflammatory responses. Annu Rev Immunol (2005) 23:821-52. doi:10.1146/annurev.immunol.23.021704.115835

34. Karsten CM, Pandey MK, Figge J, Kilchenstein R, Taylor PR, Rosas M, et al. Anti-inflammatory activity of IgG1 mediated by Fc galactosylation and association of FcgammaRIIB and dectin-1. Nat Med (2012) 18(9):1401-6. doi: $10.1038 / \mathrm{nm} .2862$

35. Ludwig RJ, Vanhoorelbeke K, Leypoldt F, Kaya Z, Bieber K, McLachlan SM, et al. Mechanisms of autoantibody-induced pathology. Front Immunol (2017) 8:603. doi:10.3389/fimmu.2017.00603

36. Fonseca MI, Ager RR, Chu SH, Yazan O, Sanderson SD, LaFerla FM, et al. Treatment with a C5aR antagonist decreases pathology and enhances behavioral performance in murine models of Alzheimer's disease. J Immunol (2009) 183(2):1375-83. doi:10.4049/jimmunol.0901005

37. Croker DE, Monk PN, Halai R, Kaeslin G, Schofield Z, Wu MC, et al. Discovery of functionally selective C5aR2 ligands: novel modulators of C5a signalling. Immunol Cell Biol (2016) 94(8):787-95. doi:10.1038/icb.2016.43
38. Kolev M, Le Friec G, Kemper C. Complement - tapping into new sites and effector systems. Nat Rev Immunol (2014) 14(12):811-20. doi:10.1038/nri3761

39. Hawlisch H, Belkaid Y, Baelder R, Hildeman D, Gerard C, Kohl J. C5a negatively regulates toll-like receptor 4 -induced immune responses. Immunity (2005) 22(4):415-26. doi:10.1016/j.immuni.2005.02.006

40. Gerard NP, Lu B, Liu P, Craig S, Fujiwara Y, Okinaga S, et al. An anti-inflammatory function for the complement anaphylatoxin C5a-binding protein, C5L2. J Biol Chem (2005) 280(48):39677-80. doi:10.1074/jbc.C500287200

41. Rittirsch D, Flierl MA, Nadeau BA, Day DE, Huber-Lang M, Mackay CR, et al. Functional roles for C5a receptors in sepsis. Nat Med (2008) 14(5):551-7. doi:10.1038/nm1753

42. Scola AM, Johswich KO, Morgan BP, Klos A, Monk PN. The human complement fragment receptor, C5L2, is a recycling decoy receptor. Mol Immunol (2009) 46(6):1149-62. doi:10.1016/j.molimm.2008.11.001

43. Bamberg CE, Mackay CR, Lee H, Zahra D, Jackson J, Lim YS, et al. The C5a receptor $(\mathrm{C} 5 \mathrm{aR}) \mathrm{C} 5 \mathrm{~L} 2 \mathrm{is}$ a modulator of C5aR-mediated signal transduction. J Biol Chem (2010) 285(10):7633-44. doi:10.1074/jbc.M109.092106

44. Zhang X, Schmudde I, Laumonnier Y, Pandey MK, Clark JR, Konig P, et al. A critical role for C5L2 in the pathogenesis of experimental allergic asthma. J Immunol (2010) 185(11):6741-52. doi:10.4049/jimmunol.1000892

45. Kemper C. Targeting the dark horse of complement: the first generation of functionally selective C5aR2 ligands. Immunol Cell Biol (2016) 94(8):717-8. doi:10.1038/icb.2016.62

46. Karsten CM, Wiese AV, Mey F, Figge J, Woodruff TM, Reuter T, et al. Monitoring C5aR2 expression using a floxed tdTomato-C5aR2 knock-in mouse. J Immunol (2017) 199(9):3234-48. doi:10.4049/jimmunol.1700710

47. Mihai S, Chiriac MT, Takahashi K, Thurman JM, Holers VM, Zillikens D, et al. The alternative pathway of complement activation is critical for blister induction in experimental epidermolysis bullosa acquisita. J Immunol (2007) 178(10):6514-21. doi:10.4049/jimmunol.178.10.6514

48. Chen M, Daha MR, Kallenberg CG. The complement system in systemic autoimmune disease. J Autoimmun (2010) 34(3):J276-86. doi:10.1016/j.jaut. 2009.11.014

49. Chen M, Jayne DRW, Zhao MH. Complement in ANCA-associated vasculitis: mechanisms and implications for management. Nat Rev Nephrol (2017) 13(6):359-67. doi:10.1038/nrneph.2017.37

50. Heppe EN, Tofern S, Schulze FS, Ishiko A, Shimizu A, Sina C, et al. Experimental laminin 332 mucous membrane pemphigoid critically involves C5aR1 and reflects clinical and immunopathological characteristics of the human disease. J Invest Dermatol (2017) 137(8):1709-18. doi:10.1016/j.jid.2017.03.037

51. Trouw LA, Pickering MC, Blom AM. The complement system as a potential therapeutic target in rheumatic disease. Nat Rev Rheumatol (2017) 13(9):53847. doi:10.1038/nrrheum.2017.125

52. Schmidt E, Reimer S, Kruse N, Jainta S, Brocker EB, Marinkovich MP, et al. Autoantibodies to BP180 associated with bullous pemphigoid release interleukin-6 and interleukin-8 from cultured human keratinocytes. J Invest Dermatol (2000) 115(5):842-8. doi:10.1046/j.1523-1747.2000.00141.x

53. Iwata H, Kamio N, Aoyama Y, Yamamoto Y, Hirako Y, Owaribe K, et al. IgG from patients with bullous pemphigoid depletes cultured keratinocytes of the $180-\mathrm{kDa}$ bullous pemphigoid antigen (type XVII collagen) and weakens cell attachment. J Invest Dermatol (2009) 129(4):919-26. doi:10.1038/jid.2008.305

54. Messingham KN, Srikantha R, DeGueme AM, Fairley JA. FcR-independent effects of $\operatorname{IgE}$ and $\operatorname{IgG}$ autoantibodies in bullous pemphigoid. J Immunol (2011) 187(1):553-60. doi:10.4049/jimmunol.1001753

55. Joly P, Roujeau JC, Benichou J, Picard C, Dreno B, Delaporte E, et al. A comparison of oral and topical corticosteroids in patients with bullous pemphigoid. N Engl J Med (2002) 346(5):321-7. doi:10.1056/NEJMoa011592

56. Feliciani C, Joly P, Jonkman MF, Zambruno G, Zillikens D, Ioannides D, et al. Management of bullous pemphigoid: the European dermatology forum consensus in collaboration with the European academy of dermatology and venereology. Br J Dermatol (2015) 172(4):867-77. doi:10.1111/bjd.13717

57. Sticherling M, Franke A, Aberer E, Glaser R, Hertl M, Pfeiffer C, et al. An open, multicenter, randomized clinical study in patients with bullous pemphigoid comparing methylprednisolone and azathioprine with methylprednisolone and dapsone. Br J Dermatol (2017) 177(5):1299-305. doi:10.1111/bjd.15649

58. Williams HC, Wojnarowska F, Kirtschig G, Mason J, Godec TR, Schmidt E, et al. Doxycycline versus prednisolone as an initial treatment strategy for bullous pemphigoid: a pragmatic, non-inferiority, randomised controlled trial. Lancet (2017) 389(10079):1630-8. doi:10.1016/S0140-6736(17)30560-3 
59. Kasperkiewicz M, Ellebrecht CT, Takahashi H, Yamagami J, Zillikens D, Payne AS, et al. Pemphigus. Nat Rev Dis Primers (2017) 3:17026. doi:10.1038/ nrdp. 2017.26

60. Schmidt E. Rituximab as first-line treatment of pemphigus. Lancet (2017) 389(10083):1956-8. doi:10.1016/S0140-6736(17)30787-0

61. Anhalt GJ, Till GO, Diaz LA, Labib RS, Patel HP, Eaglstein NF. Defining the role of complement in experimental pemphigus vulgaris in mice. J Immunol (1986) 137(9):2835-40.

62. Ujiie H, Sasaoka T, Izumi K, Nishie W, Shinkuma S, Natsuga K, et al. Bullous pemphigoid autoantibodies directly induce blister formation without complement activation. J Immunol (2014) 193(9):4415-28. doi:10.4049/ jimmunol.1400095

63. Dainichi T, Nishie W, Yamagami Y, Sonobe H, Ujiie H, Kaku Y, et al. Bullous pemphigoid suggestive of complement-independent blister formation with anti-BP180 IgG4 autoantibodies. Br J Dermatol (2016) 175(1):187-90. doi:10.1111/bjd.14411

64. Romeijn TR, Jonkman MF, Knoppers C, Pas HH, Diercks GF. Complement in bullous pemphigoid: results from a large observational study. Br J Dermatol (2017) 176(2):517-9. doi:10.1111/bjd.14822
65. Triantafilou K, Hughes TR, Triantafilou M, Morgan BP. The complement membrane attack complex triggers intracellular $\mathrm{Ca} 2+$ fluxes leading to NLRP3 inflammasome activation. JCell Sci (2013) 126(Pt 13):2903-13. doi: $10.1242 /$ jcs. 124388

66. Laudes IJ, Chu JC, Huber-Lang M, Guo RF, Riedemann NC, Sarma JV, et al. Expression and function of $\mathrm{C} 5 \mathrm{a}$ receptor in mouse microvascular endothelial cells. J Immunol (2002) 169(10):5962-70. doi:10.4049/jimmunol.169.10.5962

Conflict of Interest Statement: The authors declare that the research was conducted in the absence of any commercial or financial relationships that could be construed as a potential conflict of interest.

Copyright $\odot 2018$ Karsten, Beckmann, Holtsche, Tillmann, Tofern, Schulze, Heppe, Ludwig, Zillikens, König, Köhl and Schmidt. This is an open-access article distributed under the terms of the Creative Commons Attribution License (CC BY). The use, distribution or reproduction in other forums is permitted, provided the original author(s) and the copyright owner are credited and that the original publication in this journal is cited, in accordance with accepted academic practice. No use, distribution or reproduction is permitted which does not comply with these terms. 